\title{
Predictors of Attitudes toward Lesbian and Gay Parenting in an Ecuadorian Sample
}

\author{
Carlos Hermosa-Bosano $^{\mathrm{a}}$ (D), Paula Hidalgo-Andrade ${ }^{\mathrm{a}}$ (D) Adriana Olaya-Torres $^{\mathrm{b}}$ (D), \\ Claudia Duque-Romero $^{b}$ (D), Pedro Alexandre $\operatorname{Costa}^{c}$ (D), and Fernando Salinas-Quiroz ${ }^{d}$ (ID

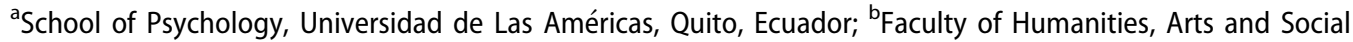 \\ Sciences, University of Ibagué, Ibagué, Colombia; 'William James Center for Research, ISPA - Instituto

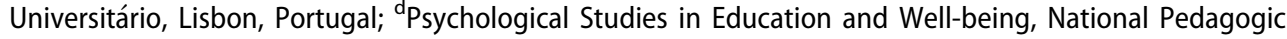 \\ University, Mexico City, Mexico
}

\begin{abstract}
In the past few years, Ecuador has experienced legal changes toward the recognition of sexual minority rights. However, lesbian and gay (LG) individuals and couples still face legal obstacles to become parents and social barriers that place their families in disadvantage compared to their heterosexual counterparts. To date, it is not known whether the legal changes reflect society's move toward a more progressive and accepting climate. This study analyzed the attitudes toward LG parenting in an Ecuadorian online-recruited sample. Three hundred thirty-eight (338) participants answered an online questionnaire about the negative effects and the benefits of having LG parents. The strongest belief among participants was that children of LG parents would be victimized because of their parents' sexual orientation. Analyses indicated differences in attitudes based on age, sexual orientation, marital status, education level, as well as religiosity. Finally, regression models suggested that beliefs about the origins of sexual orientation and contact with LG people predicted attitude scores. Implications of these findings are discussed.
\end{abstract}

\section{KEYWORDS}

Sexual prejudice; lesbian and gay parented families; gay and lesbian parents; same-sex parents; family diversity

\section{Introduction}

Since their beginning, studies on same-sex parenting have focused primarily on the analysis of children's psychological, developmental, and social outcomes, especially from lesbian (L) and gay (G) parents, and to a lesser degree, bisexual (B) and transgender (T) parents (Goldberg, 2010; Patterson, 2013; Salinas-Quiroz et al., 2020; Tasker, 2005). This body of literature has consistently suggested that parental sexual orientation and gender identity do not impact children's psychological, social, and physical well-being nor does it affect the quality of family relationships (Carneiro et al., 2017; Patterson, 2013; Stacey, 2013). For this reason, organizations such as the American Psychological Association, and the American Association of Pediatrics, among others, have issued statements supporting parenting by sexual and gender minority individuals and samesex couples (Committee on Psychological Aspects of Child and Family Health, 2002; Paige, 2005).

Despite the scientific evidence available and the increasing levels of acceptance toward sexual minorities in most parts of the world, people still hold unfounded prejudice against lesbian and gay (LG) parents' ability to provide safe and emotionally nurturing environments (Baiocco et al., 
2020; Costa et al., 2014). Research on this matter has shown the existence of two opposing positions (Frias-Navarro et al., 2015; Pacilli et al., 2011). On the one hand, there are individuals that believe that LG parenting can have detrimental effects for children because it inhibits them from growing with different-sex models that teach them socially expected gender roles. These ideas lead them to believe that children in LG parented households are more prone to develop a nonheterosexual orientation or a non-conforming gender identity. These individuals also tend to believe that children with LG parents experience higher levels of social isolation, rejection, and homophobic teasing, thus leading to higher psychological problems (Frias-Navarro et al., 2006). On the other hand, there are people that believe that the well-being of children is not related to family structure but rather to family dynamics and the quality of family relationships. Thus, LG couples can be as good parents as their heterosexual counterparts (Frias-Navarro et al., 2006).

To the best of our knowledge, no study in Ecuador has examined attitudes toward LG parenting. In the last decade, this Latin American country has promoted several legal advancements toward the recognition of sexual minority's rights such as nondiscrimination laws and same-sex marriage. However, discrimination and violence against sexual minorities, same-sex couples and their families persists, and there are no laws that allow same-sex couples to adopt and access other pathways to parenthood. Considering the lack of information on the attitudes toward LG parenting and the factors that explains them in Ecuador, we collected data through an online survey using a series of self-administered questionnaires. Understanding attitudes and the factors associated with them is a way to comprehend "the immediate environment in which people from these minorities live, which in the worst cases constitutes a source of rejection and stress and in the best cases a source of legitimization and support" (Vecho et al., 2019, p. 1). We believe this information could help identify possible targets for future intervention initiatives.

\section{LG parenting in Ecuador}

Ecuador is a country with a population of approximately 17,4 million inhabitants (INEC, 2020). Historically, religion has played an important role in shaping the political, cultural, social, and family life of its population (Ayala Mora, 1996; Buriano Castro, 2014). To this day, Ecuadorians place religion as one of the most important aspects of their life. According to the last population census, $91.9 \%$ of Ecuador's population reported having a religion. Of those, $80.4 \%$ self-identified as Catholic and 11.3\% reported being Evangelic (INEC, 2012). As with other countries in the region, the strong religious discourses have led people to adopt conservative and heterosexist views of family, gender roles, and parenthood, which frequently legitimize acts of discrimination and violence against sexual minorities, their partners, and their families (Lubbe, 2013).

Regarding LG parenting, there is no available statistical data to estimate the number of sexual minority people raising biological or adoptive children in the country. The only information available is from a 2013 survey that shows that $10.4 \%$ out of 2,805 sexual minority individuals reported having children, and among them, $85.6 \%$ were raising biologically conceived children (INEC, 2013). Moreover, $45.2 \%$ of respondents without children reported having considered becoming a parent at least once in their life (INEC, 2013).

Despite the lack of information on LG parenting, there have been important legal advances toward the recognition of sexual minority's family rights. In 2008, the Ecuadorian General Assembly changed the definition of family in the National Constitution. Specifically, it defined marriage as a product of a voluntary union between two people, excluding the previous statement that marriage was between a man and a woman. This legal change led 385 same-sex couples to enter into civil unions between 2014 and 2017 (El Telégrafo, 2017). More recently, in June 2019, the Constitutional Court allowed same-sex couples to marry (El Universo, 2019). However, there are legal obstacles for LG couples to raise and adopt children in Ecuador. Article 68 of the Ecuadorian Constitution explicitly prohibits adoption by same-sex couples (República de 
Ecuador, 2008), despite the law recognizing family diversity, civil union, marriage, the right of no discrimination based on sexual orientation, as well as children's right to have a family (República de Ecuador, 2008; Suárez Andrade \& Berni, 2017). In 2012, legal contradictions were evident in the case of two British mothers that sued the Ecuadorian State for not allowing their 6-year-old daughter to be registered as their child. In this case, the child was denied a birth certificate with both of their mothers' surnames despite them both being residents in Ecuador for 14 years, having had a civil union formalized in Ecuador and the United Kingdom, and being a couple before their daughters' birth. This case had a lot of media attention, and it was solved in 2018 when Ecuador's Constitutional Court exhorted the Civil Registry to grant the child her birth certificate (Global Voices, 2018). In spite of the case being solved, there are still a series of questions regarding the legal security of children of LG parents in the country when the biological parent dies or when couples separate.

\section{Attitudes toward LG parenting}

Research on attitudes toward LG parenting can be traced back to the 1990s. Initial studies used quasi-experimental designs and focused on participants' attitudes using real or fictional adoption cases (Crawford et al., 1999; Crawford \& Solliday, 1996; Fraser et al., 1995; McLeod et al., 1999). Crawford and Solliday (1996) used vignettes depicting the story of a couple interested in adopting a five-year-old child. The sexual orientation and the ethnicity of the prospective parents were manipulated to create four different conditions. After reading one of the vignettes, participants were asked whether they would support the adoption, their opinions on the couples' stability, and the child's physical safety and emotional security. Results indicated that students, especially those with higher levels of religiosity and anxious personality traits, viewed the gay couple as less suitable for adoption, less emotionally stable, and more likely to provide an insecure and dangerous environment for the child compared to the other heterosexual couples. Years later, Crawford et al. (1999) conducted a similar study with a sample of psychologists. They found that, regardless of participants holding affirming attitudes toward the LG couples, they were less likely to grant adoption to them when compared to their heterosexual counterparts.

The use of vignettes has been a constant practice in the field ever since (Camilleri \& Ryan, 2006; Massey, 2007; Morse et al., 2007; Rye \& Meaney, 2010). Nonetheless, several self-administered scales have been developed, especially in European countries such as Portugal (Costa et al., 2014) and Spain (Frías-Navarro, 2009; Frias-Navarro \& Monterde-I-Bort, 2012). Particularly, Costa et al. (2014) developed the Attitudes toward Gay and Lesbian Parenting Scale, an 11-item instrument directed at studying positive and negative beliefs about the impact of LG parenting on children. Similarly, Frías-Navarro (2009) developed the Scale of Beliefs about Children's Adjustment in Same-Sex Families, a 14-item instrument designed to assess two types of prejudice against LG parents: an openly negative position against LG parenting named individual opposition, and a more subtle and context-related position named normative opposition.

Altogether, these instruments have allowed the expansion of research over the last decade, covering a diverse range of topics and populations including psychologists (Weiner \& Zinner, 2015), social workers (Averett \& Hegde, 2012), university students (Costa et al., 2014; Vecho et al., 2019) and educators (Baiocco et al., 2020; Hegde et al., 2014; Herbstrith et al., 2013), among others. More recently, studies have started to compare countries and regions around the globe (Costa \& Salinas-Quiroz, 2019; D'Amore et al., 2020). D'Amore et al. (2020) published the results from a European initiative that gathered data from 13,403 self-identified heterosexual university students from seven countries across Europe (Belgium, France, Greece, Italy, Poland, Portugal, and Spain). They found that participants living in countries with more conservative legislation were less supportive of same-sex marriage and LG parenting than participants in countries with 
more progressive laws. In addition, higher levels of exposure to and greater satisfaction with relationships with sexual minority people were related to greater support to LG parenting.

In Latin America, research on attitudes toward LG parenting has been limited to a few, mainly descriptive, studies. Costa and Salinas-Quiroz (2019) conducted a study to compare the attitudes of Portuguese and Mexican undergraduate students. Regression analyses indicated that being a man, older, and highly religious predicted higher levels of sexual prejudice against LG parenting. Portuguese students were more prone to believe that children in LG parented households were more likely to face discrimination at school, whereas Mexican students tended to believe that LG parents do not care about children's best interest. In Brazil, Gusberti et al. (2019) conducted a study using an online-recruited sample of 215 individuals. In their study, $63 \%$ of participants held favorable views toward same-sex adoption, despite the majority being religious. In Colombia, Campo Arias (2016) conducted a study that focused on the attitudes toward adoption by gay men among a sample of nursery students, and more recently, Hermosa-Bosano et al. (2019) on preschool teachers. Altogether, this research suggests disparate advances across the region and important differences regarding the samples and instruments employed to measure attitudes. For instance, in the study of Gusberti et al. (2019), the authors created a 5-item survey for their study, whereas Campo Arias (2016) used a single item to measure attitudes. These methodological characteristics certainly impose difficulties in comparing attitudes toward LG parenting across countries and arriving at solid conclusions about their nature and components.

\section{Predictors of attitudes toward LG parenting}

An important area of research has been examining demographic, psychological, and cultural factors that predict attitudes toward LG parenting. Much of this research has been done in the Global North (Costa, 2021). Studies have consistently shown that gender, age, education level, religion and religiosity predict attitudes toward LG parenting. Other factors such as a person's beliefs of the origins of sexual orientation, as well the amount of contact a person has with sexual minority members have also been reported as key predictors (Costa, 2021).

Regarding gender, studies have consistently shown that heterosexual men tend to be more prejudiced toward LG parenting than women (Costa et al., 2014, 2018; Massey, 2007; Webb et al., 2017; Webb \& Chonody, 2014). As an illustration, Costa et al. (2015) carried a study using a sample of 1690 Portuguese heterosexual individuals and found that men held higher levels of sexual prejudice toward gay men, lesbians, and LG parented families than women. Heterosexism, rigid and traditional gender roles, and masculine standards regarding virility and male dominance may explain why males express less favorable attitudes (D'Amore et al., 2020; Massey, 2007; Pistella et al., 2018). According to Webb and Chonody (2014), this prescription of gender norms supports a hierarchy between the sexes and parenting roles that lead men to believe that women are naturally more skilled at parenting than men, and that gay fathers are more feminine than those who are not. These factors may also explain why some sexual minority individuals have negative attitudes toward LG parenting. Research has found that lesbians and gay men with high levels of internalized sexual stigma tend to express less support toward same-sex marriage and LG parenting (Baiocco et al., 2014; Pacilli et al., 2011; Pistella et al., 2018).

Regarding age, prior research has indicated that older people tend to be more negative toward sexual minorities and LG parents. Baiocco et al. (2013) carried out a study in Rome, Italy, with 280 heterosexual adults between 65 and 87 years old. They found that older participants had stronger prejudice and that participants were more negative toward gay male parents than lesbian mothers. According to these authors, it is possible that the social environments of higher prejudice and less contact with LG people influence older participants' views on LG parenting. Another possibility is that, as people get older, they show less abilities to regulate their responses toward stigmatized groups and individuals (Baiocco et al., 2013). 
Education level may also have a role in predicting attitudes toward LG parents. Research on attitudes toward sexual minorities and minority rights has suggested that education may be a mechanism to promote respect toward diversity and nonconformity; also, it may create higher critical thinking toward socially taught messages about sexual minorities (Ohlander et al., 2005). Regarding religion and religiosity, studies have shown that the frequency of attendance of religious services significantly predict attitudes (Whitehead, 2018; Whitehead \& Perry, 2015), because attendance of religious services reinforces traditional views on families, emphasizing the importance of marriage over cohabitation, differentiated gender roles, as well as post-marital conception of children (Gross et al., 2018). Regarding religious affiliation, in a study carried out with French heterosexual students, Gross et al. (2018) found that participants from different religious groups preferred more traditional families composed of two different-sex parents than nontraditional families. Regardless of gender, catholic participants were less favorable to LG parenting than participants without a religious affiliation.

Other research has found that beliefs about the etiology and perception of controllability of sexual orientation significantly predict attitudes toward LG parents (Costa et al., 2019; Costa \& Salinas-Quiroz, 2019; Frias-Navarro et al., 2015). According to Weiner's attribution theory (1985), individuals that view same-sex attraction as a conscious election endorse ideas that suggest "a level of choice and responsibility for same-sex relationships" (Costa et al., 2019, p. 69). On the contrary, people who believe that certain behaviors (e.g., sexual orientation) are beyond their own will, tend to eliminate moral judgments associated with them (Dar-Nimrod \& Heine, 2011). Based on this proposition, people who view sexual orientation as genetically or biologically determined tend to be less prejudiced since they view sexual orientation as a feature outside of an individuals' control or decision. In contrast, people who believe that sexual orientation is controllable, chosen or socially learned by modeling, tend to judge LG parents in a more negative fashion. Studies in this regard have found that the perception of controllability of sexual orientation directly affects attitudes toward LG parenting (Frias-Navarro et al., 2015). Also, there is evidence that etiological beliefs mediate the effects of demographic variables such as gender, age, and religiosity, on the attitudes toward LG parenting (Costa et al., 2019).

Finally, interpersonal contact with other LG individuals and parents seems to matter when developing attitudes toward sexual minorities and their families (Costa et al., 2015; Herek \& Capitanio, 1996; Vecho et al., 2019). The contact hypothesis suggests that individuals who relate with people from groups distinct from their own show higher favorability toward them, depending on factors such as the nature and quality of the relationship and the frequency of contact, among others (Costa et al., 2015; Lemm, 2006). Thus, knowing LG individuals increases the chances of reducing prejudiced views on sexual minorities and LG parenting since it allows people to question critically unfounded, culturally taught, beliefs about children and parents in samesex households.

\section{The current study}

As in other countries in Latin America, there have been improvements toward the recognition of sexual and gender minority rights in Ecuador. Until 1997, Ecuadorians who were not cisgender and/or heterosexual were persecuted and incarcerated as a consequence of their sexual orientation and gender identity. However, thanks to the work of local activist movements, there has been legal gains materialized in antidiscrimination laws, gender identity recognition, civil unions, and more recently, same-sex marriage (Vega Suriaga, 2018). Unfortunately, as Chaux et al. (2021) suggest, the legal changes in the region are not necessarily the reflection of attitudinal changes in the social context. In fact, after same-sex marriage was finally approved in 2019, a series of riots took place in different cities across the country led by conservative, faith-based movements rallying against what they called "gender ideology", an epistemological movement interested in supposedly 
imposing women and sexual minority rights (El Universo, 2019). Data from the latest Americas Barometer confirms the strong opposition to same-sex marriage as $51.3 \%$ of a nation-wide representative sample opposes it (Moncagatta et al., 2020).

The lack of information in the country regarding LG parented families and the social environments where they navigate, as well as the social and political events that have occurred in the last years, have raised questions about what people think and feel about these family configurations. Thus, the objectives of this research were threefold. First, we sought to describe the attitudes toward LG parenting using an online recruited sample of Ecuadorian individuals. Second, we analyzed potential differences based on sociodemographic characteristics (i.e., gender, age, sexual orientation, marital status, having children, education level, religion, religious affiliation, and frequency of attendance of religious services) as well as interpersonal contact variables (i.e., having LG acquaintances, friends, family members and knowing LG parented families). Finally, we tested which factors predicted attitudes toward LG parenting. In line with the empirical work previously described, we expect to find that:

H1. Men, older, heterosexual, less-educated, more religious, and people with fewer contact with sexual minority individuals will have stronger negative attitudes toward LG parenting.

H2. Etiological beliefs about the origins of sexual orientation, and interpersonal contact variables will significantly predict the attitudes toward LG parented families.

\section{Methods}

\section{Design and procedures}

Data for this article was collected in the context of an international study whose aim was to describe the attitudes toward sexual minorities, LG parenting and sexual minority rights among people from Spanish and Portuguese speaking countries in Latin America, The Caribbean, and Europe. Data was collected between May and October 2019 through an online survey available in Qualtrics, an online survey distribution platform. In Ecuador, the survey was administered in Spanish and was distributed by the first two authors. The survey was advertised through to the first two authors' personal social networks (Facebook, Instagram, WhatsApp, Twitter), and college mailing lists. The first two authors also published the link to the survey on the official Facebook account of the research group to which they belong. To take part in the study, participants had to be at least 18 years old, be a Portuguese or Spanish speaker, and live in one of the countries where the international study was taking place. Before completing the survey, participants provided their consent, which was displayed on the first page. The informed consent stipulated the study's objectives and conditions as well as information regarding possible risks and benefits. Participation was voluntary, anonymous, and people could withdraw from the study at any point. The corresponding author received IRB approval before launching the survey internationally. The study protocol was also reviewed and approved by the first authors' university.

\section{Participants}

A total sample of 407 Ecuadorian adults participated in the study. Of these, 338 completed the measures of interest; $92.6 \%$ reported living in the country at the time of the study and $7.1 \%$ reported living outside of Ecuador. One hundred seventeen $(n=117)$ individuals reported being biological males (34.6\%) and 221 biological females (65.4\%) according to their sex assigned at birth. Regarding gender, one hundred participants self-identified as men (33.6\%), 190 as women $(63.8 \%)$ and 8 as other $(2.7 \%)$. Two hundred eighty-seven participants $(n=287)$ were cisgender $(84.9 \%), 3$ were transgender $(0.9 \%), 8$ identified themselves with other gender $(2.4 \%)^{1}$ and 40 
participants did not respond (11.8\%). Age ranged from 18 to 72 years, with a mean age of 30.0 years $(S D=12.1)$. Regarding sexual orientation, $65.1 \%$ of participants identified as heterosexual, $12.4 \%$ as gay $(n=42), 5.0 \%$ as lesbian $(n=17), 14.5 \%$ as bisexual $(n=49)$, and $3.0 \%$ as other. Those who selected the option "other" self-identified as queer or pansexual. Most participants were single at the time of the study $(n=239,70.7 \%)$ and some were married $(n=59,17.5 \%) ; 18$ participants reported being on a civil union (5.3\%) and 22 reported being divorced (6.5\%). At the time of the study, $22.5 \%$ of the sample reported having children $(n=76)$.

In terms of the highest educational level achieved, 34.5\% reported having completed high school $(n=116), 37.2 \%$ completed college/undergraduate school $(n=125)$, and $28.3 \%$ completed postgraduate school $(n=95)$. Regarding religion, $37.0 \%$ participants identified as Catholic $(n=125), 8.3 \%$ as Christian $(n=28), 24.3 \%$ of participants reported being Atheist or Agnostic $(n=82), 24.6 \%$ stated being spiritual but not religious $(n=83), 0.3 \%$ were Jewish $(n=1), 0.3 \%$ Islamic, and 5.3\% reported having other religion. Regarding religious practicing, $50.3 \%$ of participants reported practicing their religion, and the majority reported attending religious services at least once a week $(n=36,41.4 \%)$.

\section{Measures}

\section{Sociodemographic questionnaire}

The sociodemographic section of the survey included questions about participants' age, sex assigned at birth, gender, sexual orientation, marital status, education level, religious affiliation, religion practice, and frequency of attendance to religious services. These questions were presented in a multiple option format at the beginning of the survey.

\section{Attitudes toward Gay and Lesbian Parenting Scale}

This scale was developed by Costa et al. (2014) and it is designed to evaluate attitudes toward LG parenting using a five-point Likert type scale that ranges from 1 (completely disagree) to 5 (completely agree). The scale has 11 items that comprise two factors, Perception of benefits and Negative perceptions of LG parenting. Higher scores on the Perception of benefits dimension suggest higher agreement with statements that suggest positive outcomes for children with LG parents (e.g., "children of gay and lesbian parents are more tolerant") as well as parent's capabilities to exercise their role in a positive manner (e.g., "there are gay and lesbian people with a high desire to have children and to be available for them). In the case of the Negative perceptions dimension, higher scores mean stronger agreement with statements about the possible negative psychological or social consequences for children with LG parents (e.g., "children of gay and lesbian parents will be homosexual or will be confused about their sexuality") as well as LG people capacities for positive parenting (e.g., "The difficulties that gay and lesbian parents face prepare them to be good parents"). Cronbach's alphas for both scales were high in this study (Perceptions of benefits dimension, $\alpha=.79$; Negative perceptions dimension, $\alpha=.87$ ).

\section{Beliefs about the Etiology of Sexual Orientation (BESO)}

This scale was developed by Frías-Navarro (2009) and consists of eight items that address the common beliefs and assumptions about the origins of a homosexual sexual orientation. It has two dimensions, Genetic etiology and Learned etiology. Genetic etiology is assessed by four items (e.g., "The homosexual sexual orientation is an inevitable behavior that depends on genetics") and the Learned etiology scale is also comprised of four items (e.g., "A child who is raised by same-sex parents will have a greater probability of having a homosexual sexual preference"). This scale uses a Likert-type response scale ranging from 1 (completely disagree) to 5 (completely agree). The higher the score in each subscale, the higher the endorsements of beliefs about genetic 
or learned etiology of homosexual orientation. Cronbach's alphas were .83 for the Genetic etiology and .89 for the Learned etiology dimension. The reliability scores obtained in this sample were slightly lower from those reported by Frias-Navarro et al. (2015) in their study with Spanish university students.

\section{Interpersonal contact with other gay/lesbian people}

The survey also included questions to identify whether people had any LG acquaintances, friends, and family members or knew any LG parented families, all measured in dichotomous 'yes' or 'no' format.

\section{Data analysis}

Descriptive statistics, correlations, independent samples t-tests, one-way analyses of variance (ANOVA), and multiple regression analyses were conducted using SPSS version 25 (IBM Corp. Inc, 2017). Multiple regression analyses were conducted to predict negative beliefs about LG parenting as well as benefits of LG parenting. Predictors included gender, age, marital status, education level, having children, religion, frequency of attendance of religious services, etiology beliefs about homosexuality, and interpersonal contact variables. For the multiple regression analyses, homoscedasticity and collinearity were investigated before conducting the analyses.

\section{Results}

\section{Descriptive analyses of attitudes toward LG parenting}

The first objective of this study was to describe the attitudes toward LG parenting. As shown in Table 1, the mean score for the negative beliefs of gay and lesbian parenting scale was 2.21 (SD $=.89$ ). The most frequently endorsed belief was item 7 which states that "Children of gay and lesbian parents are more victimized in school"; $61.5 \%$ of the respondents $(n=208)$ either agreed or highly agreed with this statement. Another item with which participants highly agreed (21.3\%, $n=72$ ) was item 9 which states that "Children of gay and lesbian parents do not have the needed masculine and feminine references for their normal development".

Regarding the perception of benefits of LG parenting, the mean score was $3.77(S D=.72)$. Item 2 which states that "The main difficulties of gay and lesbian parents are due to society prejudice" was endorsed by $82.6 \%(n=279)$ of participants. Almost $77 \%$ percent $(n=259)$ supported the belief that "There are gay and lesbian people with a high desire to have children and to be available for them". Furthermore, 65.6\% $(n=222)$ reported agreeing with the belief that "Children of gay and lesbian parents are more acceptant of other people's differences".

Pearson correlation analyses indicated high negative correlations between scales $(r=-.66, p$ $<.001)$. Higher scores on the negative perception of gay and lesbian parenting scale were significantly related to lower scores on the benefits perceptions of gay and lesbian parenting scale. Table 1 presents the correlations between items.

\section{Comparisons based on sociodemographic characteristics and interpersonal contact variables}

The second objective of this study was to analyze differences on attitudes based on sociodemographic characteristics. Table 2 shows the mean scores of each of the LG parenting attitudes scales according to the sociodemographic variables analyzed.

A one-way ANOVA based on gender did not indicate statistical differences between men, women, and those who self-identified as other. There were no statistical differences based on 
Table 1. Correlations between items of the Attitudes of Gay and Lesbian Parenting Scale.

\begin{tabular}{|c|c|c|c|c|c|c|c|c|c|c|c|}
\hline & 1 & 2 & 3 & 4 & 5 & 6 & 7 & 8 & 9 & 10 & 11 \\
\hline $\begin{array}{l}\text { 1. Gay men and lesbians should } \\
\text { not have children because it is } \\
\text { a } \sin ^{\mathrm{a}}\end{array}$ & 1 & & & & & & & & & & \\
\hline $\begin{array}{l}\text { 2. Gay and lesbian parents do } \\
\text { not care about children's } \\
\text { best interests }{ }^{\mathrm{a}}\end{array}$ & $.559^{* *}$ & 1 & & & & & & & & & \\
\hline $\begin{array}{l}\text { 3. Children of gay and lesbian } \\
\text { parents are more victimized } \\
\text { in school }\end{array}$ & $.166^{* *}$ & $.208^{* *}$ & 1 & & & & & & & & \\
\hline $\begin{array}{l}\text { 4. Children of gay and lesbian } \\
\text { parents will be homosexual or } \\
\text { will be confused about their } \\
\text { homosexuality }^{\mathrm{a}}\end{array}$ & $.657^{* *}$ & $.651^{* *}$ & $.257^{* *}$ & 1 & & & & & & & \\
\hline $\begin{array}{l}\text { 5. Children of gay and lesbian } \\
\text { parents do not have the } \\
\text { needed masculine and } \\
\text { feminine references for their } \\
\text { normal development }^{\mathrm{a}}\end{array}$ & $.568^{* *}$ & $.573 * *$ & $.234 * *$ & $.777^{* *}$ & 1 & & & & & & \\
\hline $\begin{array}{l}\text { 6. It is not natural for gay and } \\
\text { lesbians to have children }{ }^{\mathrm{a}}\end{array}$ & $.639 * *$ & $.623 * *$ & $.262^{* *}$ & $.778^{* *}$ & $.720 * *$ & 1 & & & & & \\
\hline $\begin{array}{l}\text { 7. The main difficulties of gay } \\
\text { and lesbian parents are due to } \\
\text { society prejudice }^{b}\end{array}$ & $-.542^{* *}$ & $-.538^{* *}$ & -0.052 & $-.551^{* *}$ & $-.495^{* *}$ & $-.563^{* *}$ & 1 & & & & \\
\hline $\begin{array}{l}\text { 8. The difficulties that gay and } \\
\text { lesbian parents face, prepare } \\
\text { them to be good parents }{ }^{\mathrm{b}}\end{array}$ & $-.276^{* *}$ & $-.298^{* *}$ & ${ }^{k}-.122^{*}$ & $-.378^{* *}$ & $-.319 * *$ & $-.391 * *$ & $.358^{* *}$ & 1 & & & \\
\hline $\begin{array}{l}\text { 9. Children of gay and lesbian } \\
\text { parents are more tolerant }{ }^{\mathrm{b}}\end{array}$ & $-.314^{* *}$ & $-.364^{* *}$ & ${ }^{k}-.189 * *$ & $-.432^{* *}$ & $-.421 * *$ & $-.429 * *$ & $.404^{* *}$ & $.486 * * 1$ & 1 & & \\
\hline $\begin{array}{l}\text { 10. Children of gay and lesbian } \\
\text { parents are more acceptant of } \\
\text { other people's differences }{ }^{b}\end{array}$ & $-.336^{* *}$ & $-.386^{* *}$ & ${ }^{k}-0.029$ & $-.399 * *$ & $-.341^{* *}$ & $-.410^{* *}$ & $.420^{* *}$ & $.415^{* *}$ & $.593^{* *} 1$ & 1 & \\
\hline $\begin{array}{l}\text { 11. There are gay and lesbian } \\
\text { people with a high desire to } \\
\text { have children and to be } \\
\text { available for them } \\
\text { b }\end{array}$ & $-.457^{* *}$ & $-.458^{* *}$ & ${ }^{k}-0.052$ & $-.509^{* *}$ & $-.462^{* *}$ & $-.508^{* *}$ & $.512^{* *}$ & $.342^{* *}$ & $.422^{* *}$ & $.391 * *$ & 1 \\
\hline
\end{tabular}

$* \mathrm{p}<.05 ; * \mathrm{p}<.001$.

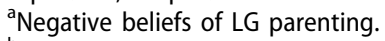

${ }^{\mathrm{b}}$ Benefits of LG parenting.

gender regarding negative beliefs, $F(2,295)=.698, p=.498$, nor benefits of LG parenting, $F(2$, $295)=2.19, p=.114$. Regarding age, results indicated that being older was positively related to perceiving greater disadvantages of LG parenting $(r=.271, p<.001)$ and negatively related to perceiving benefits $(r=-.278, p<.001)$.

Statistically significant differences based on sexual orientation were found both on perception of disadvantages, $F(4,333)=16.168, p<.001, \eta^{2}{ }_{p}=.163$, and benefits associated with LG parenting, $F(4,333)=20.378, p<.001, \eta^{2}{ }_{\mathrm{P}}=.197$. Bonferroni analysis indicated that heterosexuals perceived greater disadvantages and less benefits than those who self-identify as lesbian ( $p$ $<.001)$, gay $(p<.001)$, and bisexual $(p<.001)$. Bonferroni tests did not suggest differences between heterosexuals and individuals who identified with other sexual orientations $(p=1.00)$. Bonferroni post-hoc tests did not suggest group differences among sexual minorities $(p>.05)$.

A one-way ANOVA comparing attitudes based on marital status showed there were significant differences between groups regarding disadvantages of LG parenting, $F(3,334)=8.780, p<$ $.001, \mathrm{n}_{\mathrm{P}}^{2}=.073$. Bonferroni post-hoc tests indicated that single people perceived fewer negative effects of LG parenting than married people $(p<.001)$ and those who were divorced $(p=.037)$. There were no differences between single and those in civil unions $(p=1.00)$. Married and divorced individuals did not differ in their perceptions of negative effects of LG parenting $(p=1.00)$. Differences regarding benefits of LG parenting were also found, $F(3,334)=9.439, p$ 
Table 2. Means and standard deviations for the negative and benefits of gay and lesbian parenting scales based on sociodemographic characteristics and interpersonal contact variables.

\begin{tabular}{|c|c|c|c|c|c|}
\hline & & Negative b & parenting & Perception o & LG parenting \\
\hline & $N \quad \%$ & $M$ & $S D$ & $M$ & $S D$ \\
\hline Sex assigned at birth & & & & & \\
\hline Male & 11734.6 & 2.23 & .084 & 3.77 & .070 \\
\hline Female & 22165.4 & 2.19 & .060 & 3.76 & .048 \\
\hline Gender & & & & & \\
\hline Men & 10033.6 & 2.27 & .092 & 3.71 & .076 \\
\hline Women & 19063.8 & 2.18 & .063 & 3.78 & .051 \\
\hline Other & 82.7 & 1.96 & .188 & 4.25 & .250 \\
\hline Sexual orientation & & & & & \\
\hline Heterosexual & 22065.1 & 2.46 & .065 & 3.53 & .049 \\
\hline Gay & 4212.4 & 1.67 & .065 & 4.26 & .077 \\
\hline Lesbian & 175.0 & 1.61 & .076 & 4.16 & .115 \\
\hline Bisexual & 4914.5 & 1.73 & .056 & 4.20 & .071 \\
\hline Other & 103.0 & 2.13 & .234 & 4.02 & .175 \\
\hline Marital status & & & & & \\
\hline Single & 23970.7 & 2.07 & .053 & 3.89 & .043 \\
\hline Married & 5917.5 & 2.65 & .136 & 3.40 & .111 \\
\hline Civil union & $18 \quad 5.3$ & 2.09 & .187 & 3.74 & .149 \\
\hline Divorced & 226.5 & 2.60 & .178 & 3.45 & .142 \\
\hline Children & & & & & \\
\hline Yes & 7622.5 & 2.65 & .108 & 3.39 & .086 \\
\hline No & 26277.5 & 2.08 & .052 & 3.87 & .042 \\
\hline Educational level & & & & & \\
\hline High school & 11634.5 & 2.11 & .073 & 3.86 & .067 \\
\hline Undergraduate & 12537.2 & 2.25 & .082 & 3.79 & .059 \\
\hline Postgraduate & 9528.3 & 2.27 & .100 & 3.61 & .082 \\
\hline Religion & & & & & \\
\hline Any religion & 25675.7 & 2.37 & .059 & 3.68 & .047 \\
\hline Agnostic/Atheist & 8224.3 & 1.71 & .044 & 4.02 & .063 \\
\hline Religious affiliation & & & & & \\
\hline Christian & 288.3 & 2.77 & .186 & 3.36 & .159 \\
\hline Catholic & 12537.0 & 2.60 & .091 & 3.50 & .069 \\
\hline Jew & 10.3 & 3.00 & & 3.40 & \\
\hline Islam & 10.3 & 3.17 & & 4.00 & \\
\hline Spiritual but not religious & 8324.6 & 1.93 & .070 & 4.02 & .059 \\
\hline Agnostic/Atheist & 8224.3 & 1.71 & .044 & 4.02 & .063 \\
\hline Other & $20 \quad 5.3$ & 2.05 & .181 & 3.92 & .164 \\
\hline Religious practice & & & & & \\
\hline Yes & 8750.3 & 2.93 & .111 & 3.21 & .081 \\
\hline No & 8649.7 & 2.21 & .088 & 3.84 & .073 \\
\hline Frequency of attendance to religious servi & & & & & \\
\hline Several times a week & 1213.8 & 3.85 & .254 & 2.73 & .211 \\
\hline At least once a week & 3641.4 & 3.03 & .153 & 3.21 & .105 \\
\hline Once or twice a month & 2124.1 & 2.53 & .185 & 3.43 & .166 \\
\hline Once or twice a year & 1011.5 & 2.43 & .370 & 3.52 & .257 \\
\hline Only on holidays or religious festivities & 89.2 & 2.81 & .457 & 2.98 & .357 \\
\hline Having an acquaintance who is LG & & & & & \\
\hline Yes & 32696.4 & 2.18 & .048 & 3.80 & .039 \\
\hline No & 123.6 & 3.00 & .371 & 2.87 & .250 \\
\hline Having a friend who is $L G$ & & & & & \\
\hline Yes & 28082.8 & 2.08 & .048 & 3.88 & .040 \\
\hline No & 5817.2 & 2.82 & .137 & 3.23 & .096 \\
\hline Having a family member who is LG & & & & & \\
\hline Yes & 12938.2 & 1.99 & .066 & 3.97 & .056 \\
\hline No & 20961.8 & 2.34 & .065 & 3.64 & .052 \\
\hline Knowing a LG parent family & & & & & \\
\hline Yes & 9528.1 & 1.84 & .058 & 4.08 & .065 \\
\hline No & 24371.9 & 2.35 & .061 & 3.64 & .046 \\
\hline
\end{tabular}


$<.001, \eta^{2}{ }_{\mathrm{P}}=.078$. Single people perceived more benefits of same-sex parenting than married individuals $(p<.001)$ and divorced people $(p=.029)$; however, there were no differences between single people and individuals in civil unions $(p=1.00)$. No differences emerged between married and divorced people $(p=1.00)$. Additionally, an independent sample $t$ test indicated that those with children believed that LG parenting is disadvantageous, $t(336)=5.11, p<.001$ and less beneficial for children $t(336)=-5.26, p<.001$ than those who are not parents.

Results did not indicate statistically significant differences in the perceptions of negative effects of LG parenting according to education levels, $F(2,333)=1.169, p=.312, \eta^{2}{ }_{p}=.007$. In the case of benefits associated with LG parenting, the analyses indicated significant differences, $F(2,333)=$ $3.439, p=.033, \eta^{2}{ }_{p}=.020$. People who concluded primary and secondary school studies tended to believe more strongly that LG parenting encompasses more benefits for children compared to people with postgraduate studies $(p=.032)$. No differences were detected when comparing people with primary and secondary school studies with people with undergraduate studies $(p>.05)$.

Concerning religion, participants who reported having a religion were more prone to perceive disadvantages of LG parenting, $t(336)=6.137, p<.001$ and fewer benefits, $t(336)=-3.761, p$ $<.001$ in comparison to those who reported being agnostic or atheist. A one-way ANOVA taking into consideration religious affiliation, indicated significant differences both for negative effects of LG parenting, $F(4,331)=21.600, p<.001, \eta^{2}{ }_{p}=.207$, and perception of benefits, $F(4,331)=$ 13.397, $p<.001, \mathrm{n}_{\mathrm{P}}^{2}=.139$. Bonferroni tests indicated Christians and Catholics did not differ in terms of their perceptions of LG parenting negative effects $(p=1.00)$ and perceptions of benefits $(p=1.00)$. Christians and Catholics believed there are more negative effects and less benefits of LG parenting compared to people with other religious affiliations $(p<.05)$.

Further, individuals who reported being active practitioners of their religion believed that LG parenting involves more disadvantages, $t(171)=5.127, p<.001$ and less benefits, $t(171)=$ $-5.708, p<.001$ than those who are not. A one-way ANOVA taking into consideration the frequency of attendance to religious services showed differences in the perceptions of disadvantages of LG parenting, $F(4,82)=4.394, p<.001, \mathrm{n}^{2}{ }_{\mathrm{P}}=.177$. Bonferroni analysis did not indicate difference between those who attended religious services several times a week and those who attended at least once a week $(p=.132)$ and only on holidays $(p=.213)$. Those who attended religious services several times a week tended to believe that LG parenting carries more negative effects for children than those who attended religious services once or twice a month $(p=.003)$ and once or twice a year $(p=.010)$. Lastly, regarding benefits of LG parenting, analyses did not show statistically significant differences based on the frequency of attendance to religious services, $F(4,82)=2.369, p=.059, \eta^{2}=.104$.

Finally, independent samples t-tests based on interpersonal contact variables were carried out. Results suggested that people who had LG acquaintances, $t(336)=3.184, p<.001$, LG friends, $t$ $(336)=6.115, p<.001$, LG family members, $t(336)=3.547, p<.001$, or knew a LG-parented family, $t(336)=4.928, p<.001$ believed LG parenting carries fewer negative effects for children than those who do not. Similar results were observed when analyzing perceptions of benefits; those who had LG acquaintances, $t(336)=-4.498, p<.001$, LG friends, $t(336)=-6.493, p<$ .001 , LG family members, $t(346)=-4.163, p<.001$, or knew a LG-parented family, $t(336)=$ $-5.111, p<.001$, compared to those who did not, believed more strongly that LG parenting carries benefits for children.

\section{Predictors of attitudes toward LG parenting}

The final objective of this study was to test which factors predict attitudes toward LG parenting. Multiple regression analyses were conducted using gender, age, marital status, education level, having children, religion, frequency of attendance of religious services, etiology beliefs about 
Table 3. Multiple regression model predicting Negative beliefs of LG parenting.

\begin{tabular}{|c|c|c|c|c|}
\hline Model summary & $R_{\text {adj }}^{2}$ & $\mathrm{~F}$ & $\mathrm{df}$ & $p$ \\
\hline Initial model & .778 & 22.55 & 12 & .000 \\
\hline Final model & .772 & 146.52 & 2 & .000 \\
\hline Initial model & B & SE & $t$ & $p$ \\
\hline Constant & 1.82 & 1.01 & 1.80 & .076 \\
\hline Gender & 0.13 & 0.14 & 0.98 & .330 \\
\hline Age & 0.01 & 0.01 & 0.85 & .396 \\
\hline Marital status & -0.01 & 0.24 & -0.05 & .962 \\
\hline Educational level & -0.10 & 0.15 & -0.68 & .498 \\
\hline Children & -0.03 & 0.26 & -0.12 & .907 \\
\hline Frequency of attendance to religious services & -0.37 & 0.13 & -2.81 & .007 \\
\hline Genetic etiology & -0.07 & 0.07 & -1.07 & .287 \\
\hline Learned etiology & 0.68 & 0.06 & 10.87 & .000 \\
\hline Having an acquaintance who is LG & -0.27 & 0.23 & -1.17 & .245 \\
\hline Having a friend who is LG & -0.10 & 0.16 & -0.64 & .522 \\
\hline Having a family member who is LG & -0.09 & 0.13 & -0.65 & .517 \\
\hline Knowing a LG parented family & -0.29 & 0.15 & -1.90 & .062 \\
\hline \multicolumn{5}{|l|}{ Final } \\
\hline Constant & 1.12 & 0.24 & 4.65 & .000 \\
\hline Frequency of attendance to religious services & -0.30 & 0.11 & -2.73 & .008 \\
\hline Learned etiology & 0.75 & 0.05 & 15.92 & .000 \\
\hline
\end{tabular}

Table 4. Multiple regression model predicting perceptions of benefits of LG parenting.

\begin{tabular}{|c|c|c|c|c|}
\hline Model summary & $R_{\text {adj }}^{2}$ & $\mathrm{~F}$ & $\mathrm{df}$ & $p$ \\
\hline Initial model & .435 & 5.74 & 12 & .000 \\
\hline Final model & .438 & 66.55 & 4 & .000 \\
\hline Initial model & B & SE & $t$ & $p$ \\
\hline Constant & 3.19 & 1.15 & 2.78 & .007 \\
\hline Gender & 0.21 & 0.16 & 1.39 & .171 \\
\hline Age & 0.00 & 0.01 & -0.47 & .638 \\
\hline Marital status & -0.70 & 0.27 & -2.61 & .011 \\
\hline Educational level & 0.13 & 0.17 & 0.78 & .441 \\
\hline Children & -0.29 & 0.30 & -0.96 & .339 \\
\hline Frequency of attendance to religious services & 0.22 & 0.15 & 1.45 & .151 \\
\hline Genetic etiology & 0.12 & 0.08 & 1.53 & .131 \\
\hline Learned etiology & -0.18 & 0.07 & -2.46 & .016 \\
\hline Having an acquaintance who is LG & 0.67 & 0.27 & 2.51 & .015 \\
\hline Having a friend who is LG & 0.20 & 0.18 & 1.09 & .282 \\
\hline Having a family member who is LG & 0.29 & 0.15 & 1.97 & .053 \\
\hline Knowing a LG parented family & 0.14 & 0.17 & 0.82 & .417 \\
\hline \multicolumn{5}{|l|}{ Final } \\
\hline Constant & 3.63 & 0.21 & 16.92 & .000 \\
\hline Age & -0.01 & 0.00 & -3.07 & .002 \\
\hline Genetic etiology & 0.16 & 0.03 & 5.11 & .000 \\
\hline Learned etiology & -0.33 & 0.03 & -10.94 & .000 \\
\hline Having an acquaintance who is $L G$ & 0.65 & 0.16 & 4.00 & .000 \\
\hline
\end{tabular}

homosexuality, and interpersonal contact variables as predictors. Collinearity assumptions for the final models were met.

In the case of beliefs about the negative effects of LG parenting, analyses suggested a significant model, $F(2,86)=145.516, p=.00$ that explained $77.2 \%$ of the variance. Results revealed that learned etiology beliefs $(\beta=.840, p<.001)$ and frequency of attendance to religious services $(\beta=-.144, p=.008)$ significantly predicted negative beliefs of LG parenting. Table 3 presents the initial and final models with the $\mathrm{B}$ coefficients and standard deviations for each predictor.

Regarding benefits of LG parenting, a significant model was also found, $F(4,337)=66.551, \mathrm{p}$ $<.001$ that explained $43.8 \%$ of variance. In this model, age $(\beta=-.130, p<.001)$, genetic etiology beliefs $(\beta=.217, p<.001)$, learned etiology beliefs $(\beta=-.483, p<.001)$, and having a 
LG acquaintance $(\beta=.165, p<.001)$ significantly predicted the levels of benefits of LG parenting. Table 4 presents the initial and final models with the values for each predictor.

\section{Discussion}

In the last few years, Ecuador has been the scenario of a series of affirmative legal changes to protect sexual and gender minorities. However, some pathways to parenthood, such as adoption and the use of reproductive technologies, are still restricted to heterosexual couples. Furthermore, there are specific legal and social challenges that LG parents and their children face. The strong opposition against sexual minority rights soon after same-sex marriage was approved in 2019, has prompt the question of whether these legal advancements do reflect a more progressive, and acceptant society. Based on these ideas, we decided to conduct a study to learn more about the attitudes toward LG parenting and the factors that predict them with a sample of Ecuadorian adults.

Results from this study indicated that some participants, despite not necessarily being strongly opposed to LG parenting, do believe that having LG parents can have negative consequences for children. A closer inspection of the scores for each item of the Attitudes toward Gay and Lesbian Parenting Scale indicated that respondents endorsed the idea that children need different-sex figures to develop and that children from LG parented households are more likely to be victimized at schools. These findings are consistent with previous studies in which individuals express their concerns about potential individual and social consequences for children raised in LG parented households (Hermosa-Bosano et al., 2019; Pennington \& Knight, 2011). Nevertheless, a significant percentage of participants held positive views about LG parenting. More than $80.0 \%$ of respondents agreed with the statement that social stressors cause the difficulties experienced by LG parented families. These results suggest that participants identify society, and not people's sexual orientation, as one of the main sources of obstacles for LG parented families, which include stigma, discrimination, and violence.

We believe this information is valuable as it can inform interventions in settings such as schools and universities, worksites, health-care environments, and others, to stress the importance of transforming the social environments in which sexual minorities live to promote their well-being. Also, interventions could help people identify the strengths of LG parents. In our sample, participants agreed with the idea that LG parents experience a strong desire for parenting leading to an increase in their emotional availability, and that children from LG parents learn to be more accepting of diversity. Reaffirming these ideas, by providing empirically based information, could be a way to promote more accepting attitudes toward LG parented families. This knowledge can also be useful to inform family policies directed at creating safe environments for LG parented families.

Analyses based on the sample's sociodemographic characteristics confirmed most of our hypotheses. Consistent with previous studies, people who were older, married, had children, selfidentified as religious, actively practiced their religion, and often attended religious services tended to have less favorable attitudes toward LG parenting. On the contrary, younger, single, and sexual minorities were more prone to identify potential benefits of having LG parents. In general, these results are in line with previous literature that link these variables with measurements of homonegativity, attitudes toward LG rights and LG parenting (Baiocco et al., 2020; Chaux et al., 2021; Costa, 2021; Costa et al., 2014; Whitley, 2009).

One factor in which no significant differences were observed was gender. Results did not suggest differences neither on the scores of the negative beliefs nor the benefits scales. These findings are surprising since most of the literature suggests that (heterosexual) men are more likely than (heterosexual) women to disapprove LG parenting (Costa et al., 2014, 2018; Massey, 2007; Webb et al., 2017; Webb \& Chonody, 2014). We believe that the composition of the sample is the main explanation as to why differences were not detected. Previous research has suggested that sexual 
minorities and people with more interpersonal contact have more affirming attitudes toward LG parenting (Costa et al., 2015; Pistella et al., 2018). In our study, almost 35\% of the participants were sexual minority individuals, and most of the sample reported having LG acquaintances, friends, and family members. It is likely that these characteristics may have diluted any gender differences.

Other findings that were not entirely consistent with previous research were those regarding education levels. In this study, analyses demonstrated that those with primary and secondary school studies believed that LG parenting had more positive effects for children compared to people with postgraduate studies. However, there were no differences regarding negative effects. This finding stands out since most of the literature suggests the opposite direction (e.g., Ohlander et al., 2005). One possible interpretation is that people with higher levels of education tend to view LG parent families more equally to those with different-sex parents and for this reason they abstain from attributing characteristics that make LG families stand out from other family configurations.

Regarding our third objective, we found that etiological beliefs of sexual orientation and interpersonal contact were the strongest variables explaining levels of attitudes toward LG parenting. Like Costa and Salinas-Quiroz (2019) study that used compared samples of Portuguese and Mexican people, controllable beliefs of homosexuality predicted a high percentage of variance of the negative beliefs scores. As in previous studies, these findings suggest that constructivist positions of the origin of sexual orientation (i.e., thinking that being LG is a chosen lifestyle or something taught by external models) are related to higher levels of rejection and prejudice toward LG parents whereas essentialist, biological ideas of the origin of sexual orientation are predictors of positive judgments of same-sex parenting (Frias-Navarro et al., 2015). Other significant variables were those related to interpersonal contact with LG people. Results indicated that having an acquaintance who is LG predicted higher scores in the benefits scale. These findings supports the contact hypothesis which suggests that individuals who have access to members from groups different than their own have higher favorability toward them, depending on factors such as the nature of the relationship, the frequency of contact, among others (Costa et al., 2015; Lemm, 2006).

Altogether, these variables could be taken into consideration when designing intervention initiatives in contexts such as schools and universities, social networks, and other mass media such as television. It is possible that educational contents reinforcing the idea of sexual orientation as an uncontrollable and a biologically determined characteristic, would foster greater acceptance of LG people and same-sex parented families. In addition, deconstructing the idea that sexual orientation is a learned sexual "preference" would help reduce fears related to children growing up in LG parented households. Results also suggest that increasing the exposure to and visibility of sexual minority issues would increase acceptance of same-sex relationships and families. Creating familiarity through positive representations of same-sex parents and their children would be an important way to reduce prejudice and increase awareness of the similarities and obstacles that they encounter in heteronormative environments.

\section{Limitations and future directions}

There are some limitations in this study that need to be acknowledged. First, we used a convenience sample employing online snowball sampling methods. It is possible that the non-probabilistic procedures used in this project had a direct effect on the sample composition, their sociodemographic and ideological characteristics. For instance, $34.2 \%$ of the sample reported being gay, lesbian, bisexual or having other sexual orientation and only 50.5\% affirmed actively practicing their religion. Research have shown that Ecuador is a highly conservative country with a strong religious influence (Moncagatta et al., 2020; Pew Research Center, 2013; Tummino \& Bintrim, 2016). It is very likely that the participants in this study were more liberal than the 
general population. Future projects would benefit from other recruitment methods to obtain a sample that better represents the Ecuadorian society. Similarly, we did not gathered data on other important characteristics such as ethnicity, and socioeconomic status. Future research should take into consideration these variables to improve the generalization of results.

Another limitation is that despite all participants being Ecuadorian, 7.1\% of them reported not living in the country at the time of the study. We kept these participants since we were interested in including people based on their nationality. However, people living in other contexts may have had different attitudes because of their experiences in those environments. Future studies should take into consideration these variables as potential exclusion criteria.

One final limitation was that this study asked participants' attitudes toward LG parents, leaving behind their attitudes toward other important sexual and gender minority populations such as bisexual and transgender parents. Several authors have called researchers to pay further attention to the experiences of bisexual and transgender parents (Carneiro et al., 2017; Hicks, 2013; Ross \& Dobinson, 2013). As far as we are concerned, there is basically no information in Latin American countries regarding these issues. It would be of great use for future studies to understand the social context' characteristics of bisexual and transgender parented families. Furthermore, future research could compare the attitudes toward LG parenting based on gender identity. In this study, only $0.9 \%$ of our participants were transgender. Given the disparities in our sample based on this variable, we decided not to run comparative analyses. However, given the lack of research in the country, studying potential differences between cisgender and transgender individuals could be useful to deepen our knowledge about these issues.

\section{Conclusions}

Understanding the nature of attitudes toward LG parenting and de-constructing prejudiced views can help reduce the stigma and discrimination against sexual minorities and their families. This study has provided initial information in a context where empirical data is still missing. Given that Ecuador is a country where laws still limit sexual and gender minorities family aspirations, it is important to start identifying ways to work toward the creation of accepting environments toward LG parented families. Despite its limitations, this research has provided valuable data regarding groups that might be targeted for interventions as well important factors that help to explain people's attitudes toward LG parenting. We hope that this study ignites new research projects in a region of the world where knowledge is yet to be developed.

\section{Acknowledgments}

We would like to thank César Parra for his technical assistance during data analyses; Dr. Olimpo José García Beltrán, Director of Research at the University of Ibagué and Dr. Tannya Lozada, Head of Research at Universidad de Las Américas, and Dr. Edgar Zúñiga Salazar, Professor at the School of Psychology of Universidad de Las Américas for their support. The international study received no specific grant from any funding agency in the public, commercial, or not-for-profit sectors. The study in Ecuador was approved by the General Research Department from Universidad de Las Américas, Quito (Ecuador).

\section{Disclosure statement}

There was no conflict of interest identified during the conduction of this study.

\section{ORCID}

Carlos Hermosa-Bosano (iD http://orcid.org/0000-0001-7957-2455

Paula Hidalgo-Andrade (ID http://orcid.org/0000-0003-1797-3258 
Adriana Olaya-Torres (D) http://orcid.org/0000-0002-1376-9383

Claudia Duque-Romero (D) http://orcid.org/0000-0002-8596-2406

Pedro Alexandre Costa (iD http://orcid.org/0000-0001-9826-9881

Fernando Salinas-Quiroz (D) http://orcid.org/0000-0002-1257-6379

\section{References}

Averett, P. E., \& Hegde, A. (2012). School social work and early childhood student's attitudes toward gay and lesbian families. Teaching in Higher Education, 17(5), 537-549. https://doi.org/10.1080/13562517.2012.658564

Ayala Mora, E. (1996). El laicismo en la historia del Ecuador. Procesos, Revista Ecuatoriana de Historia, 8, 3-32.

Baiocco, R., Argalia, M., \& Laghi, F. (2014). The desire to marry and attitudes toward same-sex family legalization in a sample of Italian lesbians and gay men. Journal of Family Issues, 35(2), 181-200. https://doi.org/10.1177/ $0192513 X 12464872$

Baiocco, R., Nardelli, N., Pezzuti, L., \& Lingiardi, V. (2013). Attitudes of Italian heterosexual older adults towards lesbian and gay parenting. Sexuality Research and Social Policy, 10(4), 285-292. https://doi.org/10.1007/s13178013-0129-2

Baiocco, R., Rosati, F., Pistella, J., Salvati, M., Carone, N., Ioverno, S., \& Laghi, F. (2020). Attitudes and beliefs of Italian educators and teachers regarding children raised by same-sex parents. Sexuality Research and Social Policy, 17(2), 229-238. https://doi.org/10.1007/s13178-019-00386-0

Buriano Castro, A. (2014). El “espíritu nacional” del Ecuador católico: política y religión. Procesos, Revista Ecuatoriana de Historia, 40, 63-89.

Camilleri, P., \& Ryan, M. (2006). Social work students' attitudes toward homosexuality and their knowledge and attitudes toward homosexual parenting as an alternative family unit: An Australian study. Social Work Education, 25(3), 288-304. https://doi.org/10.1080/02615470600565244

Campo Arias, A. (2016). Aceptación de la adopción por hombres homosexuales en estudiantes de medicina. Revista Colombiana de Enfermería, 6(6), 29. https://doi.org/10.18270/rce.v6i6.1431

Carneiro, F. A., Tasker, F., Salinas-Quiroz, F., Leal, I., \& Costa, P. A. (2017). Are the fathers alright? A systematic and critical review of studies on gay and bisexual fatherhood. Frontiers in Psychology, 8, 1636. https://doi.org/10. 3389/fpsyg.2017.01636

Chaux, E., León, M., Cuellar, L., \& Martínez, J. (2021). Public opinion toward LGBT people and rights in Latin America and the Caribbean. In Oxford research encyclopedia of politics (pp. 1-41). Oxford University Press. https://doi.org/10.1093/acrefore/9780190228637.013.1941

Committee on Psychological Aspects of Child and Family Health. (2002). Coparent or second-parent adoption by same-sex parents. Pediatrics, 109(2), 339-340. https://doi.org/10.1542/peds.109.2.339

Costa, P. A. (2021). Attitudes toward LGB families: International policies and LGB family planning. In Oxford research encyclopedia of politics (pp. 1-25). Oxford University Press. https://doi.org/10.1093/acrefore/9780190228637.013.1177

Costa, P. A., Almeida, R., Anselmo, C., Ferreira, A., Pereira, H., \& Leal, I. (2014). University students' attitudes toward same-sex parenting and gay and lesbian rights in Portugal. Journal of Homosexuality, 61(12), 1667-1686. https://doi.org/10.1080/00918369.2014.951253

Costa, P. A., Carneiro, F. A., Esposito, F., D’Amore, S., \& Green, R. J. (2018). Sexual prejudice in Portugal: Results from the first wave European study on heterosexual's attitudes toward same-gender marriage and parenting. Sexuality Research and Social Policy, 15(1), 99-110. https://doi.org/10.1007/s13178-017-0292-y

Costa, P. A., Pereira, H., \& Leal, I. (2015). The "contact hypothesis" and attitudes toward same-sex parenting. Sexuality Research and Social Policy, 12(2), 125-136. https://doi.org/10.1007/s13178-014-0171-8

Costa, P. A., Pereira, H., \& Leal, I. (2019). Through the lens of sexual stigma: Attitudes toward lesbian and gay parenting. Journal of GLBT Family Studies, 15(1), 58-75. https://doi.org/10.1080/1550428X.2017.1413474

Costa, P. A., \& Salinas-Quiroz, F. (2019). A comparative study of attitudes toward same-gender parenting and gay and lesbian rights in Portugal and in Mexico. Journal of Homosexuality, 66(13), 1909-1926. https://doi.org/10. 1080/00918369.2018.1519303

Crawford, I., McLeod, A., Zamboni, B. D., \& Jordan, M. B. (1999). Psychologists' attitudes toward gay and lesbian parenting. Professional Psychology: Research and Practice, 30(4), 394-401. https://doi.org/10.1037/0735-7028.30.4.394

Crawford, I., \& Solliday, E. (1996). The attitudes of undergraduate college students toward gay parenting. Journal of Homosexuality, 30(4), 63-77. https://doi.org/10.1300/J082v30n04_04

D’Amore, S., Wollast, R., Green, R.-J., Bouchat, P., Costa, P. A., Katuzny, K., Scali, T., Baiocco, R., Vecho, O., Mijas, M. E., Aparicio, M. E., Geroulanou, K., \& Klein, O. (2020). Heterosexual university students' attitudes toward same-sex couples and parents across seven European countries. Sexuality Research and Social Policy, (114). https://doi.org/10.1007/s13178-020-00511-4

Dar-Nimrod, I., \& Heine, S. J. (2011). Genetic essentialism: On the deceptive determinism of DNA. Psychological Bulletin, 137(5), 800-818. https://doi.org/10.1037/a0021860 
El Telégrafo. (2017). Los GLBTI acceden a las uniones en la región. https://www.eltelegrafo.com.ec/noticias/sociedad/6/los-glbti-acceden-a-las-uniones-en-la-region\#: :text=Los\%20colectivos\%20diversos\%2C\%20en\%20la,leyes\% 20a\%20favor\%20de\%20ellos.

El Universo. (2019). Corte Constitucional de Ecuador admite el matrimonio igualitario. https://www.eluniverso.com/ noticias/2019/06/12/nota/7374447/corte-constitucional-ecuador-admitematrimonio-igualitario

Fraser, I. H., Fish, T. A., \& MacKenzie, T. M. (1995). Reactions to child custody decisions involving homosexual and heterosexual parents. Canadian Journal of Behavioural Science/Revue Canadienne Des Sciences Du Comportement, 27(1), 52-63. https://doi.org/10.1037/0008-400X.27.1.52

Frías-Navarro, D. (2009). Scale of beliefs about children's adjustment in same-sex families. https://www.uv.es/ $\sim$ friasnav/Scale_Spanish.pdf

Frias-Navarro, D., \& Monterde-I-Bort, H. (2012). A scale on beliefs about children's adjustment in same-sex families: Reliability and validity. Journal of Homosexuality, 59(9), 1273-1288. https://doi.org/10.1080/00918369.2012.720505

Frias-Navarro, D., Monterde-I-Bort, H., Pascual-Soler, M., \& Badenes-Ribera, L. (2015). Etiology of homosexuality and attitudes toward same-sex parenting: A randomized study. Journal of Sex Research, 52(2), 151-161. https:// doi.org/10.1080/00224499.2013.802757

Frias-Navarro, D., Pascual-Llobell, J., Monterde-I-Bort, H., \& Montejano Sánchez, S. (2006). Creencias sobre la parentalidad de parejas del mismo: causas de la homosexualidad. Interpsiquis, 1, 1-19.

Global Voices (2018). In Ecuador, a young girl wins the right to have the surnames of both her mothers. https:// globalvoices.org/2018/06/21/in-ecuador-a-young-girl-wins-the-right-to-have-the-surnames-of-both-her-mothers/

Goldberg, A. E. (2010). Lesbians and gay men as parents. In A.E. Goldberg, Division 44: Contemporary perspectives on lesbian, gay, and bisexual psychology. Lesbian and gay parents and their children: Research on the family life cycle (pp. 89-123). American Psychological Association. https://doi.org/10.1037/12055-004

Gross, M., Vecho, O., Gratton, E., D’Amore, S., \& Green, R.-J. (2018). Religious affiliation, religiosity, and attitudes toward same-sex parenting. Journal of GLBT Family Studies, 14(3), 238-259. https://doi.org/10.1080/1550428X. 2017.1326016

Gusberti, J. D. d. S., Klaime, S., Kaufert, T. L., \& Silva, D. (2019). Pesquisa de opinião sobre adoção homoafetiva no Brasil. Brazilian Journal of Health Review, 2(4), 3518-3532. https://doi.org/10.34119/bjhrv2n4-115

Hegde, A. V., Averett, P., Parker White, C., \& Deese, S. (2014). Examining preschool teachers' attitudes, comfort, action orientation and preparation to work with children reared by gay and lesbian parents. Early Child Development and Care, 184(7), 963-976. https://doi.org/10.1080/03004430.2013.845563

Herbstrith, J. C., Tobin, R. M., Hesson-McInnis, M. S., \& Joel Schneider, W. (2013). Preservice teacher attitudes toward gay and lesbian parents. School Psychology Quarterly: The Official Journal of the Division of School Psychology, American Psychological Association, 28(3), 183-194. https://doi.org/10.1037/spq0000022

Herek, G. M., \& Capitanio, J. P. (1996). Some of "my best friends" intergroup contact, concealable stigma, and heterosexuals' attitudes toward gay men and lesbians. Personality and Social Psychology Bulletin, 22(4), 412-424. https://doi.org/10.1177/0146167296224007

Hermosa-Bosano, C., Vargas-Trujillo, E., \& Ripoll-Núñez, K. (2019). Actitudes, percepciones de autoeficacia y prácticas de docentes de preescolar hacia el trabajo con familias homoparentales en Bogotá. Summa Psicológica UST, 16(2), 110-120. https://doi.org/10.18774/0719-448.x2019.16.415

Hicks, S. (2013). Lesbian, gay, bisexual, and transgender parents and the question of gender. In A. E. Goldberg \& K. R. Allen (Eds.), LGBT-parent families (pp. 149-162). Springer. https://doi.org/10.1007/978-1-4614-4556-2_10

IBM Corp. Inc. (2017). IBM statistics for windows, version 25.0. IMB Corp.

INEC. (2012). Primeras estadísticas oficiales sobre filiación religiosa en el Ecuador (p. 17). http://www.ecuadorencifras.gob.ec//documentos/web-inec/Estadisticas_Sociales/Filiacion_Religiosa/presentacion_religion.pdf

INEC. (2013). Estudio de Caso sobre condiciones de vida, inclusión social y cumplimiento de derechos humanos de la población LGBTI del Ecuador. https://www.ecuadorencifras.gob.ec/documentos/web-inec/Estadisticas_Sociales/ LGBTI/Analisis_situacion_LGBTI.pdf\%0D

INEC. (2020). Ecuador en cifras. https://www.ecuadorencifras.gob.ec/estadisticas/

Lemm, K. M. (2006). Positive associations among interpersonal contact, motivation, and implicit and explicit attitudes toward gay men. Journal of Homosexuality, 51(2), 79-99. https://doi.org/10.1300/J082v51n02_05

Lubbe, C. (2013). LGBT parents and their children: Non-western research and perspectives. In A. E. Goldberg \& K. R. Allen (Eds.), LGBT-parent families (pp. 209-223). Springer. https://doi.org/10.1007/978-1-4614-4556-2_14

Massey, S. G. (2007). Sexism, heterosexism, and attributions about undesirable behavior in children of gay, lesbian, and heterosexual parents. Journal of GLBT Family Studies, 3(4), 457-483. https://doi.org/10.1300/J461v03n04_05

McLeod, A. C., Crawford, I., \& Zechmeister, J. (1999). Heterosexual undergraduates' attitudes toward gay fathers and their children. Journal of Psychology \& Human Sexuality, 11(1), 43-62. https://doi.org/10.1300/J056v11n01_03

Moncagatta, P., Moscoso Moreno, A., Pachano, S., Montalvo, D. J., \& Sechmeister, E. J. (2020). Cultura politica de la democracia en Ecuador y en las Américas, 2018/2019: Tomándole el pulso a la democracia. USAID. https:// www.vanderbilt.edu/lapop/ecuador/AB2018-19_Ecuador_Country_Report_V2_W_02.03.20.pdf 
Morse, C., McLaren, S., \& McLachlan, A. (2007). The attitudes of Australian heterosexuals toward same-sex parents. Journal of GLBT Family Studies, 3(4), 425-455. https://doi.org/10.1300/J461v03n04_04

Ohlander, J., Batalova, J., \& Treas, J. (2005). Explaining educational influences on attitudes toward homosexual relations. Social Science Research, 34(4), 781-799. https://doi.org/10.1016/j.ssresearch.2004.12.004

Pacilli, M. G., Taurino, A., Jost, J. T., \& van der Toorn, J. (2011). System justification, right-wing conservatism, and internalized homophobia: Gay and lesbian attitudes toward same-sex parenting in Italy. Sex Roles, 65(7-8), 580-595. https://doi.org/10.1007/s11199-011-9969-5

Paige, R. U. (2005). Proceedings of the American Psychological Association for the Legislative Year 2004: Minutes of the Annual Meeting of the Council of Representatives, February 20-22, 2004, Washington, DC, and July 28 and 30, 2004, Honolulu, Hawaii, and Minutes of the Febr. American Psychologist, 60(5), 436-511. https://doi. org/10.1037/0003-066X.60.5.436[Mismatch]

Patterson, C. J. (2013). Family lives of lesbian and gay adults. In G. W. Peterson \& K. R. Bush (Eds.), Handbook of marriage and the family (pp. 659-681). Springer Science \& Business Media. https://doi.org/10.1007/978-1-46-143887-5_27

Pennington, J., \& Knight, T. (2011). Through the lens of hetero-normative assumptions: Re-thinking attitudes towards gay parenting. Culture, Health \& Sexuality, 13(1), 59-72. https://doi.org/10.1080/13691058.2010.519049

Pew Research Center. (2013). The global divide on homosexuality: Greater acceptance in more secular and affluent countries. http://www.pewglobal.org/files/2013/06/Pew-Global-Attitudes-Homosexuality-Report-FINAL-JUNE-42013.pdf

Pistella, J., Tanzilli, A., Ioverno, S., Lingiardi, V., \& Baiocco, R. (2018). Sexism and attitudes toward same-sex parenting in a sample of heterosexuals and sexual minorities: the mediation effect of sexual stigma. Sexuality Research and Social Policy, 15(2), 139-150. https://doi.org/10.1007/s13178-017-0284-y

República de Ecuador. (2008). Constitución Política del Ecuador. In Registro Oficial (Vol. 449, p. 67). http://www. asambleanacional.gov.ec/documentos/constitucion_de_bolsillo.pdf

Ross, L. E., \& Dobinson, C. (2013). Where is the "B" in LGBT parenting? A call for research on bisexual parenting. In A. E. Goldberg \& K. R. Allen (Eds.), LGBT-parent families (pp. 87-103). Springer. https://doi.org/10.1007/ 978-1-4614-4556-2_6

Rye, B. J., \& Meaney, G. J. (2010). Self-defense, sexism, and etiological beliefs: Predictors of attitudes toward gay and lesbian adoption. Journal of GLBT Family Studies, 6(1), 1-24. https://doi.org/10.1080/15504280903472485

Salinas-Quiroz, F., Costa, P. A., \& Lozano-Verduzco, I. (2020). Parenting aspiration among diverse sexual orientations and gender identities in Mexico, and its association with internalized homo/transnegativity and connectedness to the LGBTQ community. Journal of Family Issues, 41(6), 759-783. https://doi.org/10.1177/0192513X19881675

Stacey, J. (2013). Foreword. In A. E. Goldberg \& K. R. Allen (Eds.), Handbook of LGBT-parent families: Innovations in research and implications for practice (pp. v-viii). Springer Science + Business Media. https://doi. org/10.1007/978-1-4614-4556-2

Suárez Andrade, G., \& Berni, P. (2017). La adopción homoparental como medida de protección de los derechos del menor en el ordenamiento jurídico ecuatoriano. Espirales, Revista Multidisciplinaria de Investigación, 8, 1-19.

Tasker, F. (2005). Lesbian mothers, gay fathers, and their children: A review. Journal of Developmental \& Behavioral Pediatrics, 26(3), 224-240. https://doi.org/10.1093/acprof:oso/9780195082319.003.0011 https://doi. org/10.1097/00004703-200506000-00012

Tummino, A., \& Bintrim, R. (2016). Índice de Inclusión Social. Americas Quarterly, 10(4), 2-15.

Vecho, O., Gross, M., Gratton, E., D’Amore, S., \& Green, R. J. (2019). Attitudes toward same-sex marriage and parenting, ideologies, and social contacts: The mediation role of sexual prejudice moderated by gender. Sexuality Research and Social Policy, 16(1), 44-57. https://doi.org/10.1007/s13178-018-0331-3

Vega Suriaga, E. (2018). De gays y trans a diversidades sexo/genéricas: dos décadas de despenalización de la homosexualidad en Ecuador. INTERdisciplina, 7(17), 119-153. https://doi.org/10.22201/ceiich.24485705e.2019.17.67524

Webb, S. N., \& Chonody, J. (2014). Heterosexual attitudes toward same-sex marriage: The influence of attitudes toward same-sex parenting. Journal of GLBT Family Studies, 10(4), 404-421. https://doi.org/10.1080/1550428X. 2013.832644

Webb, S. N., Chonody, J. M., \& Kavanagh, P. S. (2017). Attitudes toward same-sex parenting: An effect of gender. Journal of Homosexuality, 64(11), 1583-1595. https://doi.org/10.1080/00918369.2016.1247540

Weiner, B. A., \& Zinner, L. (2015). Attitudes toward straight, gay male, and transsexual parenting. Journal of Homosexuality, 62(3), 327-339. https://doi.org/10.1080/00918369.2014.972800

Whitehead, A. L. (2018). Homosexuality, religion, and the family: The effects of religion on Americans' appraisals of the parenting abilities of same-sex couples. Journal of Homosexuality, 65(1), 42-65. https://doi.org/10.1080/ 00918369.2017.1310550

Whitehead, A. L., \& Perry, S. L. (2015). A more perfect union? Christian nationalism and support for same-sex unions. Sociological Perspectives, 58(3), 422-440. https://doi.org/10.1177/0731121415577724

Whitley, B. E. (2009). Religiosity and attitudes toward lesbians and gay men: A meta-analysis. International Journal for the Psychology of Religion, 19(1), 21-38. https://doi.org/10.1080/10508610802471104 